\title{
Velimir Petrović, Esekerski rječnik / Essekerisches Wörterbuch, drugo, dopunjeno i poboljšano izdanje; FF Press, Zagreb 2020.
}

Nakon prvogizdanja Esekerskog rječnika autora Velimira Petrovića kojeje objavljeno 2008. godine kao udžbenik Sveučilišta Josipa Jurja Strossmayera u Osijeku i Sveučilišta u Zagrebu i koje je, kako doznajemo iz predgovora, rasprodano u nekoliko mjeseci, dvanaest godina kasnije u izdanju FF pressa iz tiska je izašlo drugo, dopunjeno i prošireno izdanje. Zbog velikog zanimanja kulturne javnosti i struke autor je odlučio dopuniti i proširiti rječnik, na čemu je predano radio do svoje smrti 2018. godine. Rad na dopunama pratila je Snježana Babić te je dovršila i uskladila rukopis za drugo izdanje rječnika.

Rječniku njemačkog dijalekta grada Osijeka odnosno esekerskog narječja (str. 3-478) prethode Predgovor na hrvatskome jeziku (str. II) i Predgovor na njemačkome jeziku (str. III) urednika drugoga izdanja Tihomira Engela i Zrinjke Glovacki-Bernardi, Zahvala Velimira Petrovića preuzeta iz prvoga izdanja na hrvatskome (str. IV) i njemačkome jeziku (str. V) te isječak Iz Predgovora prvom izdanju na hrvatskome (str. VI-VIII) i njemačkome jeziku (str. IX-X). Prije rječnika naveden je Popis znakova i kratica na hrvatskome (str. XI) i njemačkome jeziku (str. XII), a nakon rječnika nalazi se popis Osječkih ulica i trgova (str. 479) s imenima koje su nosile 1893., 1920. i 2001. godine te popis Gradskih četvrti Osijeka (str. 480) s usporednim nazivima na njemačkom, esekerskom i hrvatskom. Navedeni su i biografski podaci autora esekerskih tekstova na hrvatskome (str. 481-482) i njemačkome jeziku (str. 483-484) i popis korištene literature (str. 485-486), rječnika (str. 487-488) i izvora (str. 489).

Iz Predgovora doznajemo u kojem je opsegu proširen i čime je upotpunjen ovaj rječnik u odnosu na prvo izdanje. Drugo izdanje ima sedamdesetak stranica više jer sadrži dodatne podatke dobivene obradom razgovora s govornicima esekerskog 1995. godine i u rječnik uvrštene hrvatske posuđenice koje su koristili govornici esekerskog narječja. Usto su pridodani popisi osječkih ulica, trgova i gradskih četvrti te podaci o autorima esekerskih tekstova.

Više o esekerskom narječju, cilju i koncepciji rječnika otkriva nam autorov predgovor iz prvog izdanja. Esekerski ili tzv. esekersko narječje njemački je dijalekt grada Osijeka koji je nastao spajanjem više bavarsko-austrijskih dijalekata s leksičkim elementima jezika u dodiru, od kojih dominiraju razgovorni njemački jezik austrijske varijante kojim su govorili pripadnici obrazovanijeg sloja njemačke etničke skupine te hrvatski, srpski i mađarski jezik. Esekerski je do kraja Drugog svjetskog rata bio jezik sporazumijevanja nižih društvenih slojeva njemačkog stanovništva grada Osijeka, no zbog poslijeratnih političkih prilika i drastičnog smanjivanja broja njemačkih stanovnika, esekerski dijalekt sve se više gubio pa danas više nema govornika ovoga dijalekta. 
Autor ističe da je rječnik namijenjen čitateljima esekerskih tekstova koji imaju poteškoća s razumijevanjem nekih jezičnih elemenata, ali i istraživačima koje zanima proučavanje ovog gradskog dijalekta. Kad je riječ o ustroju samoga rječnika, leksičke su jedinice smještene $u$ kontekst koji je preuzet iz materijala odnosno korpusa na kojem se temelji rječnik. To su prije svega tekstovi na esekerskom dijalektu osječkog publicista Luje Pleina, novinara Vladimira Hafnera i Ernsta Dirnbacha objavljeni od 1929. do 1940. godine te Miroslava Stilinovića koji su nastali krajem 20. stoljeća. Za riječi izvan konteksta autor rječnika sam je osmislio primjere. Uz svaku esekersku jedinicu stoji i njemački odnosno hrvatski ekvivalent, navedene su postojeće inačice, a osim standardnojezičnih, uz unose se nalaze i elementi razgovornogjezika.

U predgovoru je autor također iznio neke napomene o rodu, broju i pisanju imenica te glagolskim oblicima uspoređujući esekerske riječi s njemačkim i hrvatskim ekvivalentima. Osvrnuo se i na sastavljeno (fonetsko) pisanje skupine riječi onako kako se izgovaraju te na naglasak koji je u esekerskom dijalektu dinamičan i u pravilu istovjetan naglasku u standardnom njemačkom jeziku. U tom kontekstu autor spominje neujednačenost izgovora esekerskog među govornicima, ovisno o utjecaju materinskog dijalekta, jezika u dodiru i njemačkog jezika kao nastavnog predmeta u školama. Predgovor završava osvrtom na složenost esekerskog dijalekta u pisanome obliku. Naime, fonetski se karakter hrvatskoga pisma samo djelomično podudara s esekerskim dijalektom, te je stoga hrvatskim čitateljima koji nisu dovoljno upoznati s razgovornim ili standardnim njemačkim jezikom čitanje esekerskih tekstova otežano. Isto vrijedi i za njemačke čitatelje ako ne poznaju hrvatski grafijski sustav.

Za ilustraciju leksičkih jedinica odabrani su jedna imenica i jedan glagol, s obzirom na to da autor u predgovoru rječniku ističe obilježja tih dviju vrsta riječi:

ga $^{\mathrm{I}} \mathrm{t}^{\mathrm{t}}{ }^{\mathrm{s}} \mathrm{sund}$, gajst $\mathrm{t}^{\mathrm{s}}$ tund, die $=$ Geisterstunde (die Stunde von Mitternacht bis ein Uhr) • ponoć, gluho doba noći (vrijeme između ponoći i jedan sat): ton nemts traj grousi fiškradn inda gaistaštund unt pinc afjeida kradn a kšekatigas pandl rauf $(\mathrm{P})=$ dann nehmt drei große Fischgräten in der Geisterstunde und bindet an jede Gräte ein scheckiges Bandel • potom uzmite u gluho doba noći tri velike riblje kosti i vežite na svaku kost šarenu vrpcu.

Uz esekersku imenicu stoji rod (u ovom je primjeru riječ o ženskom rodu, die) te njemački i hrvatski ekvivalent s pojašnjenjem u zagradama. Zatim slijedi primjer iz esekerskog korpusa, odnosno riječ u kontekstu. Slovo P u zagradama upućuje na to da je primjer preuzet iz Pleinova teksta, što je moguće iščitati iz popisa znakova i kratica koji prethodi rječniku. Esekerski je primjer popraćen prijevodom na njemački i hrvatskijezik.

šịmpfn (kšịmpft) (h) = schimpfen • grditi: Hot si kšimpft iba mia? (P) = Hat sie geschimpft über mich? • Je li me grdila?; Jec hot ti Ani onfonkt cu šimpfn (S) = 
Jetzt hat die Anni angefangen zu schimpfen. • Sad je Ana počela grditi; Ton hoc onkfonkt. East hom si mih kšimpft in ajganam dialekt, vorum oabajt ih sou fil unt voz ih mea fadin ols ti ondrn $(S)=$ Dann hat's angefangen. Erst haben sie mich geschimpft im eigenen Dialekt, weil ich so viel arbeite und mehr verdiene als die anderen. • Onda je počelo. Prvo su me grdili na svom dijalektu što tako mnogo radim i što više zarađujem od drugih.

Esekerski je glagol naveden u infinitivu i participu perfekta s naznakom pomoćnog glagola za tvorbu perfekta, što je u ovom slučaju glagol haben. Nakon toga slijede standardnonjemački i hrvatski ekvivalent te konkretni primjeri uporabe u kontekstu, i to jedan primjer iz Pleinova teksta i dva primjera iz Stilinovićevih tekstova. Esekerski su primjeri popraćeni prijevodom na njemački i hrvatski jezik.

Već na temelju dviju odabranih jedinica primjetno je da rječnik sadrži vrlo detaljne natuknice, a svaki je unos ilustriran i potkrijepljen konkretnim primjerima iz korpusa koji obuhvaća i pisane tekstove i razgovorni jezik. Recepcija prvog izdanja rječnika potvrdila je da je riječ o iznimno vrijednom doprinosu ne samo hrvatskoj nego i njemačkoj leksikografiji, a drugo dopunjeno izdanje dodatno obogaćuje dokumentiranu riznicu esekerskog leksičkog blaga. Također valja istaknuti značaj konkretnih primjera esekerskog jezika i govora. Za jezikoslovce koji se bave proučavanjem ugroženih jezika i dijalekata oni su vrijedan izvor podataka za buduća istraživanja, dokje za Esekere i njihove potomke ovaj rječnik pisani spomenik u kojem je zabilježen važan dio njihove jezične povijesti. 